Journal Economics and Management (JECMA)

Volume 1, No. 02, Februari 2021, p. 10-17

\title{
Strategi Pemasaran Industri Ukir (Rancak Gamelan) Desa Karangasem, Manyaran Kab. Wonogiri Sebagai Desa Sentra Industri Kayu
}

\author{
Carving Industry Marketing Strategy (Rancak Gamelan) Karangasem Villages, \\ Manyaran Wonogiri Regency As Wood Industry Centre Villages \\ Lyly Katniati*1, Ecclisia Sulistyowati ${ }^{2}$, Umi Salamah ${ }^{3}$, Wahyu Adhi Saputro ${ }^{4}$ \\ ${ }_{1,2}$ Program Studi Manajemen, Fakultas Hukum dan Bisnis, Universitas Duta Bangsa Surakarta, \\ Indonesia \\ ${ }^{3,4}$ Program Studi Agribisnis, Fakultas Sains dan Teknologi, Universitas Duta Bangsa Surakarta, \\ Indonesia

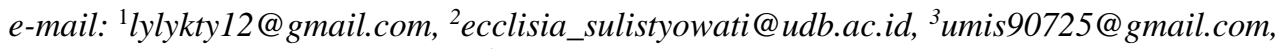 \\ ${ }^{4}$ wahyuadhi@udb.ac.id
}

\begin{abstract}
ABSTRAK
Era globalisasi dimana pasar menyediakan banyak sekali berbagai macam produk yang dijual. Perdagangan global saat ini telah dilakukan di seluruh negara di dunia. Rancak gamelan memang bukan komoditas utama dalam ekspor, tetapi rancak gamelan turut andil dalam meningkatkan devisa negara ini. Dalam hal ini, dapat dikatakan bahwa industri rancak gamelan Indonesia mulai mengembangkan pasarnya. Penelitian ini bertujuan untuk menganalisis strategi pemasaran industri ukir (rancak gamelan) Desa Karangasem. Penelitian ini menggunakan dua data yaitu data primer dan data sekunder. Data primer didapatkan dengan cara melakukan wawancara menggunakan alat kuesioner dengan responden sejumlah 30 orang yang terbagi ke dalam produsen dan konsumen. Data sekunder merupakan data yang diperoleh dari sumber data yang sudah ada dan relevan seperti jurnal, buku dan tulisan yang mendukung penelitian ini. Alat analisis yang digunakan dalam penelitian kualitatif ini seperti analisis SAP dan analisis SWOT. Kekuatan yang ada dalam industri ukir (rancak gamelan) adalah kualitas produk yang dihasilkan cukup baik. Salah satu kelemahan yang ada adalah dari sisi sumber daya manusia yang mengelola dan control pada bagian produksi. Peluang yang dapat dimanfaatkan oleh industri ukir (rancak gamelan) Desa Karangasem adalah pengembangan untuk pasar ekspor yang masih terbuka lebar. Tantangan yang harus dihadapi oleh industri ukir (rancak gamelan) Desa Karangasem adalah adanya pesaing-pesaing baru yang akan bermunculan. Jika didasarkan pada hasil SAP maka dapat dikategorikan bahwa sentra industri ukir (rancak gamelan) berada pada posisi kuat dengan skor 3,25.
\end{abstract}

Kata kunci: Industri Ukir (rancak gamelan), Strategi Pemasasran, SWOT, SAP

\begin{abstract}
The era of globalization where the market provides a wide variety of products for sale. Global trade is currently carried out in all countries in the world. Rancak gamelan is not the main commodity in exports, but rancak gamelan has contributed to increasing the country's foreign exchange. In this case, it can be said that the Indonesian gamelan industry is starting to develop its market. This study aims to analyze the marketing strategy of the carving industry (rancak gamelan) in Karangasem Village. This study uses two data, namely primary data and secondary data. Primary data is obtained by conducting interviews using a questionnaire with 30 respondents, divided into producers and consumers. Secondary data is data obtained from existing and relevant data sources such as journals, books and writings that support this research. The analytical tools used in this qualitative research such as SAP analysis and SWOT analysis. The strength that exists in the carving industry (rancak gamelan) is that the quality of the product produced is quite good. One of the weaknesses that exist is in terms of human resources who manage and control in the production department. The opportunity that the Karangasem village carving (rancak gamelan) industry can exploit is the development of the export market which is still wide open. The challenge that must be faced by the carving industry (rancak gamelan) in Karangasem Village is the presence of new competitors that will emerge. If it is based on the SAP results, it can be categorized that the carving industry center (rancak gamelan) is in a strong position with a score of 3.25 .
\end{abstract}

Keywords: Carving Industry (rancak gamelan), Marketing Strategy, SWOT, SAP

Submitted: 2021, Accepted: 2021, Published: Februari 2021

ISSN: 2746-0568 (online), Website: http://jurnal.umus.ac.id/index.php/jecma 
Journal Economics and Management (JECMA), Volume 1, No. 1, Agustus 2021, p. 10-17

\section{INTRODUCTION}

Era globalisasi dimana pasar menyediakan banyak sekali berbagai macam produk yang telah mengalami pengembangan di banyak bidang dalam sektor ekonomi dan memulai pegerakan di sektor industri [1]. Harapan dari adanya hal tersebut tentunya akan meningkatkan daya beli masyarakat terhadap produk yang tersedia di bidang industri[2]. Pesatnya perkembangan dan persaingan yang ketat juga dialami oleh industri sentra ukir kayu bahkan beberapa produk dapat di ekspor ke luar negeri. Adanya persaingan ketat tersebut membuat pengusaha di bidang industri kayu tersebut berlomba-lomba meningkatkan kualitas produk yang akan dijualnya. Banyaknya produk yang terjual di pasar yang sejenis atau homogeny membuat konsumen riskan untuk berpindah dari satu produk ke produk yang lain. Fenomena yang ada tersebut seharusnya pengusaha industry ukir harus memenuhi apa yang diinginkan sehingga sesuai dengan ekspektasi konsumen ketika membeli produk tersebut.

Perdagangan global saat ini telah dilakukan di seluruh negara di dunia. Bagi suatu negara yang melakukan perdagangan ke luar negeri jauh lebih menguntungkan daripada suatu negara menjalankan perdagangan dalam negeri. Perdagangan ke luar negeri memberikan devisa, memperluas pemasaran produk, dan dapat menambah pendapatan suatu negara. Indonesia memiliki banyak komoditi ekspor terutama rancak gamelan. Rancak gamelan memang bukan komoditas utama dalam ekspor, tetapi rancak gamelan turut andil dalam meningkatkan devisa negara ini. Dalam hal ini, dapat dikatakan bahwa industri rancak gamelan Indonesia mulai mengembangkan pasarnya. Ketersediaan bahan baku, kebudayaan, dan tenaga kerja menjadikan usaha rancak gamelan mulai diminati karena usaha ini memiliki potensi besa runtuk dikembangkan.

Desa Karangasem, Kelurahan Punduhsari, Kecamatan Manyaran, Kabupaten Wonogiri adalah salah satu desa penghasil rancakan gamelan yang fokus pada produk ekspor, yang telah berhasil menjual produknya hingga ke luar negeri seperti Asia. Bahkan dari beberapa pembeli, pembeli dapat menjalin kerjasama yang relatif lama dan berhasil mendapatkan pembeli dan pelanggan dari beberapa loyal buyer. Reputasi dan kekuatan produk yang dimiliki sehingga membuat usaha rancakan gamelan di Desa Karangasem, Kelurahan Punduhsari, Kecamatan Manyaran, Kabupaten Wonogiri semakin percaya diri dalam melakukan pemasaran ke luar negeri. Meskipun demikian, setiap usaha tentunya memiliki ancaman yang menghambat dalam pemasaran ini, bahkan mengancam kelangsungan usaha. Meskipun telah menjalin kerjasama dengan pasar luar negeri, namun ada beberapa pasar yang gagal dimasuki produk ini. Oleh karena itu, dikhawatirkan strategi pemasaran di Desa Karangasem tidak dapat terealisasikan.

Keadaan inilah yang membuat peneliti melakukan penelitian yang bertujuan untuk menganalisis strategi pemasaran industri ukir (rancak gamelan) Desa Karangasem, Kelurahan Punduhsari, Kecamatan Manyaran, Kabupaten Wonogiri sebagai desa sentra industri kayu dalam menembus pasar internasional. Berdasarkan latar belakang yang telah dikemukakan, maka penelitian ini bertujuan untuk mengetahui strategi pemasaran industri ukir (rancak gamelan) desa karangasem, manyaran kab. wonogiri sebagai desa sentra industri kayu.

\section{LITERATURE REVIEW}

Bisnis usaha yang belakangan ini semakin banyak dan semakin berkembang. Hal tersebut juga terlihat pada perkembangan bisnis yang bergerak dan dilakukan oleh home industry. Namun memang naik turunnya pergerakan bisnis rumahan banyak yang tidak bertahan lama hanya ketika sedang hype saja perkembangan produk. Keterpurukan bisnis rumahan dipengaruhi oleh beberapa faktor seperti masih sederhananya sistem manajemen bisnis yang ada, modal yang terbatas serta konsumen yang berpindah mencari produsen lain membuat kehilangan konsumen pada produk 
Journal Economics and Management (JECMA), Volume 1, No. 1, Agustus 2021, p. 10-17

home industri. Mempertahankan konsumen untuk menjadi pelanggan memanglah bagian hal berat yang harus dilakukan oleh bagian pemasaran dikarenakan akan mempengaruhi pendapatan, produk yang terjual dan perkembangan usaha. Dengan begitu strategi pemasaran yang tepat merupakan solusi dari permasalahan yang ada dalam memasarkan produk. Strategi pemasaran juga disebut sebagai alat dasar yang dapat direncanakan sematang mungkin untuk menggapai tujuan perusahaan agar produk yang terjual memiliki daya saing. Daya saing juga diperuntukkan untuk mempertahankan produk agar mampu bersaing di pasar[3].

Keterlibatan banyak pihak dalam pemasaran suatu produk yang dihasilkan membuat pemasaran menjadi intrumen penting. Keterlibatan kerja tersebut mencakup hilirisasi produk maupun jasa yang dilakukan dari sisi produsen hingga ke tangan konsumen. Rangkaian kegiatan yang dilakukan untuk membuat produk, mengenalkan, menawarkan sehingga terjadi transaksi pembelian sesuai dengan kebutuhan konsumen, klien maupun masyarakat umum dinamakan sebagai proses pemasaran[4][5]. Pemasaran juga disebut sebagai proses sosial yang membuat individu terhadap individu maupun individu terhadap kelompok untuk memperoleh yang masingmasing butuhkan dan inginkan dengan cara menukarkan jasa yang bernilai[6].

Keseluruhan konsep yang menceritakan alur sebuah perusahaan yang bergerak untuk mengatur perusahaan tersebut dan semua kegiatan di dalamnya dengan dalih agar usaha yang dijalankan berjalan sesuai rencana dan tujuan yang telah tersususun secara terstruktur dan didalamnya terjadi persaingan serta pembagian hasil kepada pemegang saham disebut dengan strategi[7][8]. Strategi pemasaran sering disebut sebagai tersusunnya tujuan dan sasaran disertai dengan aturan yang telah tersusun untuk menggapai keduanya kepada pemasaran perusahaan yang berjalan seiringnya waktu pada masing-masing divisi dengan dukungan alokasi dan acuan yang baik. Hal tersebut nantinya juga akan ada feedback dari perusahaan dalam menanggulangi dampak dari adanya persaingan yang memungkinkan mengalami perubahan dari waktu ke waktu. Keberhasilan pengusaha dalam menangani adanya persaingan akan berujung pada keberhasilan begitu juga sebaliknya perusahaan yang tidak dapat mengikuti perubahan dan menangani persaingan akan berada pada titik kegagalan. Persaingan merupakan bentuk dari aktivitas perusahaan yang memaksa dan menuntut adanya pengembangan sehingga membuat kinerja yang lebih meningkat diikuti dengan adanya inovasi dan pelaksanaan yang baik. Tentunya perusahaan harus unggul dalam beberapa aspek seperti memberikan harga yang menarik, memilik pangsa pasar yang baik, citra merk di mata konsumen yang baik, kualitas produk yang unggul sehingga memuaskan konsumen dan memiliki saluran distribusi[9] [7].

\section{METHODS}

Penelitian ini menggunakan dua data yaitu data primer dan data sekunder. Data primer didapatkan dengan cara melakukan wawancara menggunakan alat kuesioner dengan responden sejumlah 30 orang yang terbagi ke dalam produsen dan konsumen. Observasi secara mendalam dilakukan dipandu oleh peneliti dengan menggunakan kuesioner semi terstuktur. Pemilihan responden didasarkan pada pertimbangan bahwa responden merupakan seorang yang ahli dalam bidang usaha industri ukir berserta konsumen pembeli produk industri ukir tersebut. Data sekunder merupakan data yang diperoleh dari sumber data yang sudah ada dan relevan seperti jurnal, buku dan tulisan yang mendukung penelitian ini. Alat analisis yang digunakan dalam penelitian kualitatif ini seperti analisis SAP dan analisis SWOT. Analisis SAP (Strategy Advantage Profile) merupakan alat analisis yang digunakan dalam mengetahui kekuatan dan kelemahan perusahaan jika dibandingkan dengan usaha yang homogeny serta diketahuinya lebih jelas mengenai faktor-faktor internal dari perusahaan. Analisis SAP ini dapat tersusun nantinya ke dalam 6 kriteria bagi pengusaha yang terbagi ke dalam dominan, strong, favorable, sedang, lemah, tidak ada harapan. Analisis ini juga diperuntukkan untuk memetakan keunggulan dan mempersempit kelemahan dengan pertimbangan aspek yang akan berpengaruh di masa mendatang, memilih strategi dan identifikasi hal yang seharusnya di upgrade dari perusahaan tersebut. Alat analisis lanjutan yang digunakan adalah analsisi SWOT yang terpetakan ke dalam 
Journal Economics and Management (JECMA), Volume 1, No. 1, Agustus 2021, p. 10-17

empat aspek yaitu strength, weakness, opportunity, dan threat. Kekuatan merupakan sisi keunggulan maupun kondisi dimana peta kekuatan organisasi atau perusahaan pada kondisi terkini. Kelemahan menyangkut dengan adanya kegiatan organisasi yang berjalan dengan baik atau tidak didasarkan pada sumber daya yang dimiliki oleh organisasi tersebut. Peluang merupakan faktor yang muncul dari adanya peluang dan lingkungan yang memunculkan sisi positif yang dapat dimanfaatkan oleh perusahaan tersebut ke depannya.

\section{RESULTS AND DISCUSSION}

\section{Analisis Faktor Internal dan Eksternal}

\section{Faktor Internal}

Kekuatan yang termasuk ke dalam faktor internal terbagi ke dalam beberapa aspek seperti hubungan dengan lingkungan sekitar, teknologi, kualitas produk, harga produk, posisi dan ketersediaan bahan baku serta promosi. Lingkungan sekitar merupakan lingkungan pendukung yang menghubungkan pengusaha dengan masyarakat disekitarnya yang biasa disebut dengan CSR (Corporate Social Responsibility)[10]. Bentuk yang biasa dilakukan seperti pengadaan kegiatan bersama dengan warga dan memberikan bantuan pada lingkungan masyarakat sekitar. Teknologi juga dirasa mendukung adanya kekuatan pada usaha sentra industri ukir (rancak gamelan) Desa Karangasem. Pengerjaan sentra industri dengan manual membuat hasil dari industri ukir (rancak gamelan) Desa Karangasem menjadi lebih baik dan maksimal. Kualitas produk yang dihasilkan cukup baik dapat diikuti dengan adanya penjualan yang meningkat, perluasan pasar serta adanya kerja sama dengan buyer dalam waktu yang cukup panjang. Harga produk ditetapkan dengan perhitungan yang akurat. Hal tersebut dibuktikan dengan tidak adanya komplain dari pembeli terkait harga yang diberikan. Posisi dan ketersediaan bahan baku dengan adanya lokasi yang baik sehingga memperoleh bahan baku tidak terlalu mengalami kesulitan. Media promosi menjadi peranan penting yang bisa dilakukan untuk memasarkan produk. Banyaknya pelanggan sehingga word of mouth juga bisa membantu dalam meningkatkan pemasaran produk.

Kelemahan juga salah satu faktor internal yang harus dan perlu diketahui bagi pengusaha khususnya di industry ukir (rancak gamelan). Salah satu kelemahan yang ada adalah dari sisi sumber daya manusia yang mengelola dan control pada bagian produksi. Hal tersebut memang sulit dikendalikan karena sudah menjadi budaya sehingga kinerja kurang optimal serta kesulitan dalam mengatur. Design produk juga menjadi kelemahan bagi sentra industri ukir. Hal ini dikarenakan jarangnya produk mengalami inovasi dikarenakan ingin mempertahankan produk yang ada padahal pengembangan produk baru harus dilakukan oleh pengusaha untuk mempertahankan produk pada persaingan yang ada di pasar. Dapat disimpulkan bahwa perusahaan kurang mampu memberikan produk yang inovatif sehingga dikatakan rendah. Masalah brand atau merk juga menjadi sisi kelemahan dikarenakan memang banyaknya produk homogeny dari wilayah Jepara yang menjadi pesaing utama dari sentra industri ukir (rancak gamelan).

Analisis SAP dilakukan dengan cara memberikan nilai pada indikator maupun rating pada faktor internal yang meliputi kekuatan dan kelemahan. Faktor internal yang meliputi kekuatan dan kelemahan pengusaha tersebut akan diuraikan pada tabel SAP (Strategic Advantages Profile). Berikut ini adalah penjelasan tabel hasil rekap perhitungan faktor internal sentra industri ukir yang tergambar pada tabel 1.

Tabel 1. Hasil Rekap Perhitungan Faktor Internal Sentra Industri Ukir (Rancak Gamelan)

\begin{tabular}{lccc}
\hline \multicolumn{1}{c}{ Indikator Internal } & Bobot & Skala & Nilai Tertimbang \\
\hline Hubungan dengan & 0,08 & 3,46 & 0,27 \\
Lingkungan Sekitar & & & \\
Teknologi & 0,15 & 3,39 & 0,51 \\
Kualitas Produk & 0,15 & 4,00 & 0,59 \\
Harga produk & 0,12 & 3,5 & 0,42
\end{tabular}


Journal Economics and Management (JECMA), Volume 1, No. 1, Agustus 2021, p. 10-17

\begin{tabular}{lccc} 
Ketersediaan Bahan & 0,12 & 3,67 & 0,44 \\
Baku & 0,12 & 3,22 & 0,38 \\
Promosi & 0,08 & 2,94 & 0,24 \\
Sumber Daya & 0,12 & 2,00 & 0,24 \\
$\begin{array}{l}\text { Manusia } \\
\text { Design }\end{array}$ & & \\
Pengembangan & & & \\
Produk & 0,06 & 2,67 & 0,16 \\
Merk & $\mathbf{1 , 0 0}$ & $\mathbf{3 , 2 5}$ \\
\hline Total & &
\end{tabular}

Berdasarkan tabel 1 dapat diketahui bahwa hasil rekap perhitungan faktor internal terbagi ke dalam dua aspek yaitu kekuatan dan kelemahan. Pada tabel 1 diketahui nilai tertimbang dari indikator yang ada pada aspek kekuatan dan kelemahan. Indikator pada aspek kekuatan terbagi ke dalam hubungan dengan lingkungan sekitar, teknologi, kualitas produk, harga produk, ketersediaan bahan baku dan promosi sedangkan aspek kelemahan tergambar dari indikator sumber daya manusia, pengembangan produk dan citra merk. Berdasarkant tabel 1 dapat diketahui bahwa nilai SAP sebesar 3,25. Berikut ini adalah tabel posisi SAP yang dijelaskan pada tabel 2.

Tabel 2. Posisi SAP (Strategic Advantages Profile) industri Ukir (Rancak Gamelan)

\begin{tabular}{lcc}
\hline \multicolumn{1}{c}{ Posisi } & Kelas Interval & Posisi SAP \\
\hline Dominan & $3,50-4,00$ & \\
Kuat & $\mathbf{3 , 0 0}-\mathbf{3 , 5 0}$ & $\mathbf{3 , 2 5}$ \\
Aman & $2,50-3,00$ & \\
Bertahan & $2,00-3,00$ & \\
Lemah & $1,50-2,00$ & \\
Hilang Harapan & $1,00-1,50$ & \\
Sumber : Analisis Data Primer &
\end{tabular}

Jika didasarkan pada hasil SAP maka dapat dikategorikan bahwa sentra industri ukir (rancak gamelan) berada pada posisi kuat dengan skor 3,25. Hal ini menandakan bahwa usaha atau bisnis sentra industri ukir memiliki cukup peluang yang bebas dalam jangka yang panjang dan aman untuk menjual produk yang dibuat walaupun peluang dari pesaing juga ada. Kualitas produk diyakini baik dari hasil sentra industri ukir rancak gamelan sehingga posisi penjualan di pasar cenderung kuat. Dengan begitu dapat disimpulkan bahwa faktor internal usaha sentra industri ukir (rancak gamelan) adalah 3,25 yang berarti berada posisi yang kuat. Posisi yang masuk kategori kuat berada pada rentang skor 3,00 hingga 3,50. Posisi tersebut juga menandakan bahwa sentra industri ukir (rancak gamelan) memiliki kekuatan tertentu untuk bertahan dan memperbaiki kondisi hingga batas rata-rata sehingga usaha ini dapat berjalan lama.

\section{Faktor Eksternal}

Peluang (opportunity) merupakan salah satu aspek yang masuk ke dalam faktor eksternal. Informasi pada masa kini yang dapat diakses dengan mudah membuat banjirnya pesanan bagi pengrajin untuk membuka kesempatan untuk menerima kritik dan saran dari pihak lain. Adanya hal tersebut maka pengrajin secara tidak langsung mendapatakan pelatihan dan bimibingan agar produk yang dihasilkan semakin baik dan berkembang. Produk yang dihasilkan oleh industri ukir (rancak gamelan) Desa Karangasem memanglah masih sebagian besar penyerapan dilakukan oleh pasar lokal. Dengan begitu ke depannya hasil dari produk industri ukir (rancak gamelan) Desa Karangasem dapat mengalami pengembangan untuk pasar ekspor yang terbuka lebar. Seharusnya perhatian terhadap fasilitas yang diberikan oleh pemerintah setempat atau daerah untuk mendukung berkembangnya industri ukir (rancak gamelan) Desa Karangasem harus lebih. Dukungan yang dimaksud adalah dukungan dari penyediaan bahan baku, tenaga kerja terampil 
Journal Economics and Management (JECMA), Volume 1, No. 1, Agustus 2019, p. X-XX

yang ada di sekitar wilayah tersebut sehingga dapat menyerap tenaga kerja lokal. Pasar internasional yang masih terbuka lebar dan dicintainya produk Indonesia khususnya yang berasal dari industri ukir membuat terbukanya peluang sehingga diperlukan juga pelatihan untuk meningkatkan kesadaran industri ukir bahwa segmentasi pasar dapat dilebarkan dan masih ada pasar yang cukup tinggi untuk menampung banyak produk yang dihasilkan. Selain itu sisa dari bahan baku yang digunakan bisa digunakan untuk membuat kerajinan lain yang mencirikan daerah tersebut.

Tantangan (treat) juga merupakan salah satu faktor eksternal selain peluang (opportunity). Ketatnya persaingan industri ukir membuat terdapat peta persaingan antara pengrajin satu dengan pengrajin lainnya khususnya industri ukur di wilayah yang sama dan memunculkan persaingan dengan daerah lainnya. Dengan begitu pengrajin harus memiliki kelebihan dalam produk yang dibuatnya sehingga butuh adanya sesuatu yang unik dan inovasi. Adanya hal tersebut nantinya akan memberikan perbedaan antara produk satu dengan produk lainnya sehingga dapat merebut konsumen di dalam pasar yang sama. Akan tetapi para pengrajin tentunya tidak secara mudah dapat melakukan hal tersebut dengan keterbatasan modal yang ada sehingga manajemen dan pengelolaan konvensional harus diupgrade lebih kekinian yang diinovasikan dengan teknologi. Harapan kedepannya dengan beralihnya manajemen konvensional ke modern dapat membantu permodalan lebih fleksibel dan manajemen yang lebih luwes. Sebenarnya produk yang dihasilkan dari industri ukir (rancak gamelan) Desa Karangasem sudah cukup baik namun tetap harus ada pengembangan ke depannya sehingga pengrajin diwajibkan bisa menggunakan teknologi terbaru yang sudah ada sehingga produk lebih baik lagi. Hal tersebut dikarenakan teknologi yang digunakan saat ini masihlah terbatas. Munculnya pelaku industri baru sebagai pesaing baru tidak dapat dipungkiri kehadirannya sehingga tantangan tersebut harus dijawab dan diselesaikan dengan penguatan bahan baku yang tersedia setiap waktu serta adanya keterbukaan pasar bebas sehingga memperluas jangkauan produk yang dijual. Adanya penurunan permintaan produk disaat pandemic membuat imbas penutupan beberapa produk yang kurang laku dipasaran juga menjadi tantangan tersendiri dalam mengembangkan industri ukir (rancak gamelan) Desa Karangasem.

\section{CONCLUSION}

Berdasarkan hasil penelitian dapat diketahui faktor internal dan faktor eksternal yang menjadi strategi pengembangan industri ukir (rancak gamelan). Faktor internal yang terdiri dari kekuatan dan kelemahan. Kekuatan yang ada dalam industri ukir (rancak gamelan) adalah kualitas produk yang dihasilkan cukup baik dapat diikuti dengan adanya penjualan yang meningkat, perluasan pasar serta adanya kerja sama dengan buyer dalam waktu yang cukup panjang selain itu dari sisi harga produk ditetapkan dengan perhitungan yang akurat sehingga lebih terjangkau. Salah satu kelemahan yang ada adalah dari sisi sumber daya manusia yang mengelola dan control pada bagian produksi. Faktor eksternal terdiri dari peluang dan tantangan. Peluang yang dapat dimanfaatkan oleh industri ukir (rancak gamelan) Desa Karangasem adalah pengembangan untuk pasar ekspor yang masih terbuka lebar. Tantangan yang harus dihadapi oleh industri ukir (rancak gamelan) Desa Karangasem adalah adanya pesaing-pesaing baru yang akan bermunculan. Jika didasarkan pada hasil SAP maka dapat dikategorikan bahwa sentra industri ukir (rancak gamelan) berada pada posisi kuat dengan skor 3,25.

\section{REFERENCES}

[1] T. P. H. Atmoko, "Strategi Pemasaran Untuk Meningkatkan Volume Penjualan Di Cavinton Hotel Yogyakarta," J. Indones. Tour. Hosp. Recreat., vol. 1, no. 2, pp. 83-96, 2018, doi: 10.17509/jithor.v1i2.13769.

[2] F. Kereh, A. L. Tumbel, S. S. R. Loindong, J. Manajemen, U. Sam, and R. Manado, 
Journal Economics and Management (JECMA), Volume 1, No. 1, Agustus 2019, p. X-XX

"Analisis Strategi Pemasaran Dalam Meningkatkan Penjualan Motor Yamaha Mio Pada Pt. Hasjrat Abadi Outlet Yamaha Sam Ratulangi," J. EMBA J. Ris. Ekon. Manajemen, Bisnis dan Akunt., vol. 6, no. 2, pp. 968-977, 2018, doi: 10.35794/emba.v6i2.20024.

[3] D. Diniaty and A. Agusrinal, "Perancangan Strategi Pemasaran Pada Produk Anyaman Pandan," J. Sains Teknol. dan Ind., vol. 11, no. 2, pp. 175-184, 2014, doi: http://dx.doi.org/10.24014/sitekin.v11i2.745.

[4] C. L. Hutama and H. Subagio, "ANALISA PENGARUH DINING EXPERIENCE TERHADAP BEHAVIORAL INTENTION DENGAN CUSTOMER SATISFACTION SEBAGAI VARIABEL INTERVENING ( STUDI KASUS : DOMICILE KITCHEN AND LOUNGE )," J. Manaj. Pemasar., vol. 2, no. 1, 2014.

[5] K. Iskandar and W. Andriyani, "Pengaruh Strategi Pemasaran Terhadap Penjualan Batubara Pada PT. Cahaya Mantingan Nusantara Jakarta," J. Ekon. Kuantitatif Terap., vol. 7, no. 1, pp. 24-34, 2014, doi: https://doi.org/10.24843/JEKT.2014.v07.i01.p04.

[6] K. Karnelis, "Pengaruh Bauran Pemasaran terhadap Keputusan Kosumen Menggunakan Jasa Hotel Kartika Langsa,” J. Manaj. dan Keuang., vol. 6, no. 1, pp. 719-728, 2017.

[7] T. Galpin, J. L. Whittington, and G. Bell, "Is your sustainability strategy sustainable? Creating a culture of sustainability," Corp. Gov., vol. 15, no. 1, pp. 1-17, 2015, doi: 10.1108/CG-01-2013-0004.

[8] J. Fraser, "Creating shared value as a business strategy for mining to advance the United Nations Sustainable Development Goals," Extr. Ind. Soc., vol. 6, no. 3, pp. 788-791, 2019, doi: 10.1016/j.exis.2019.05.011.

[9] D. H. Wibowo, Z. Arifin, and S. Sunarti, "ANALISIS STRATEGI PEMASARAN UNTUK MENINGKATKAN DAYA SAING UMKM ( Studi pada Batik Diajeng Solo )," J. Adm. Bisnis, vol. 29, no. 1, pp. 59-66, 2015.

[10] R. Setiadi, K. L. Batu, and H. Soesanto, "Does an environmental marketing strategy influence marketing and financial performance? a study of Indonesian exporting firms," Market-Trziste, vol. 29, no. 2, pp. 177-192, 2017, doi: 10.22598/mt/2017.29.2.177. 